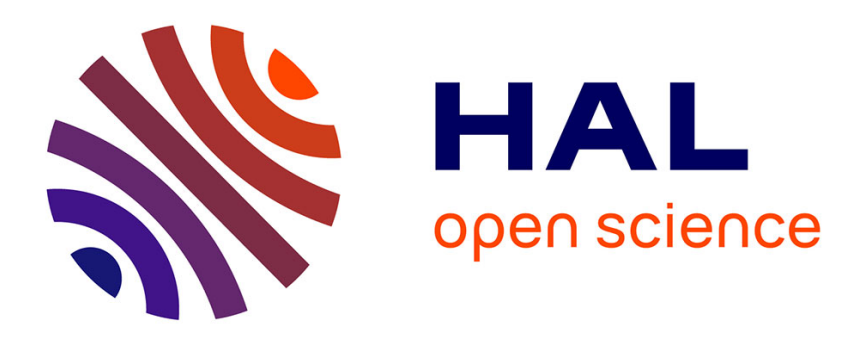

\title{
A quantitative analysis of spermatogenesis in the trout, Salmo trutta fario
}

Roland Billard

\section{To cite this version:}

Roland Billard. A quantitative analysis of spermatogenesis in the trout, Salmo trutta fario. Cell and Tissue Research, 1983, 230 (3), pp.495-502. 10.1007/BF00216195 . hal-01606071

\section{HAL Id: hal-01606071 https://hal.science/hal-01606071}

Submitted on 2 Jun 2020

HAL is a multi-disciplinary open access archive for the deposit and dissemination of scientific research documents, whether they are published or not. The documents may come from teaching and research institutions in France or abroad, or from public or private research centers.
L'archive ouverte pluridisciplinaire HAL, est destinée au dépôt et à la diffusion de documents scientifiques de niveau recherche, publiés ou non, émanant des établissements d'enseignement et de recherche français ou étrangers, des laboratoires publics ou privés. 


\title{
A quantitative analysis of spermatogenesis in the trout, Salmo trutta fario
}

\author{
R. Billard
}

Laboratoire de Physiologie des Poissons, I.N.R.A. Jouy-en-Josas, France

Summary. The pattern of spermatogenesis was studied during an annual reprodutive cycle in adult male brown trout. The part of the testicular volume occupied by the nuclei of germ cells and of Sertoli cells, the lobular lumen and the extra-lobular space were measured. The number of germ cells was estimated by the total volume occupied by each cell divided by the individual volume of each cell. The permanent number of spermatogonia A (spermatogonia isolated or in groups of 2) was about 50 million. Each GA cell produced several spermatogenetic waves during the same reprodutive cycle. Sperm production was about $25 \times 10^{9} / \mathrm{g}$ of testis/year, or about $6.8 \times 10^{7} / \mathrm{g}$ of body weight/year.

Males stocked separately from females, thus presumably not releasing spermatozoa, were killed in December, January and February. Since these fish contained the same amount of spermatozoa it appears that the process of spermiation initiated in December did not continue in January and February. During this period, some spermatozoa were phagocytized by macrophages (spermatophages) in the lobular lumen and by Sertoli cells.

Key words: Spermatogenesis - Quantitative analysis - Brown trout Spermatogenetic production

Only a few quantitative analyses of spermatogenesis in teleost fish have been published. These studies used several techniques, the simplest being the counting of the number of cells per surface unit. However, due to wide seasonal variations in the size of the testis, only the relative percentage of different types of cells, and not their true number, can be determined (e.g., Bhatti and Al-Daham 1978). A method for studying spermatogenesis in the guppy, Poecilia reticulata (Billard 1969), based on counting the 
number of cysts and their cells, cannot be applied to salmonids because it is difficult to identify the cysts. The technique used in higher vertebrates, based on counting the number of cells per tubule sections, is onerous to apply to fish because the sections of branched seminiferous tubules are heterogenous in form and diameter. Therefore, when using this technique, sections of the same size must be studied (Billard, unpublished).

Another technique for quantitative analysis, based on an estimate of the volume of the testicular cells and using an ocular integrator, has been developed for studying spermatogenesis in the goldfish (Billard et al. 1974). This method was employed in the present work, after correction, on the pattern of spermatogenesis in the brown trout during an annual reproductive cycle in which we tried to estimate the number of germ cells in the testis.

\section{Materials and methods}

In this investigation, we sampled brood fish monthly between April 1969 and February 1970; the sexes were raised separately on a private fish-farm in Normandy (Pisciculture de la Bigottière). This population has a relatively late period of reproduction with an ovulatory peak in December. The males that we employed as experimental models had not been used for artificial insemination on the fish-farm.

As soon as they arrived at the laboratory, 5 to 10 males were anesthetized with $100 \mathrm{mg} / \mathrm{l}$ of MS222, weighed and killed. When they were spermiating, sperm volume was measured and its concentration determined by using a Thoma counting chamber. The testes were weighed to the nearest $\mathrm{mg}$ and their volume was measured by water displacement. One fraction of the median part of the testis was fixed in Bouin-Holland solution for 2 days. The weight and volume of this piece was measured before embedding in paraffin. Histological sections of $5 \mu \mathrm{m}$ were cut perpendicularly to the longitudinal axis of the testis and stained with hematoxylin orange-G and aniline blue.

Quantitative analysis was based on an estimation of the volume of the nuceli of the various cell types in the testis. The volume fraction, $V_{V}$, of a structure was obtained by measuring the average areal fraction, $A_{A}$, determined on sections through a volume (Underwood 1970; Solari 1973). The areal fraction was estimated by a point counting grid composed of 25 points. This grid was established by Henning and Meyer-Arendt (1963) and commercialized under the name of Zeiss I ocular integrator. We counted the nuclear structures in 60 microscopic fields $(\times 480)$ of 1 or 2 testicular sections per male $(1,500$ points $)$ to obtain an estimate of the part of the surface occupied by the nuclear structure, $A_{A}$ and the volume $V_{V}$. The total volume, $V$, in the whole testis was then $V_{V} \times$ testicular volume. The volume $V_{V}$ was corrected for the Holmes effect according Weibel (1979):

$K\left(V_{V}\right)=\frac{1}{1+(3 / 2) g}$

in which $g$ is the relative section thickness $t / d$ ( $t$ is the average thickness of the section $=5 \mu \mathrm{m}$ and $\mathrm{d}$ is the corrected diameter of the nuclei). The cells were considered to be spherical and the apparent nuclear diameter was measured in 30 to 50 germ cells taken from each of 5 males in full spermatogenesis (August). A correction was used to calculate the diameter $\bar{D}$ for each male:

$\overline{\mathrm{D}}=\overline{\mathrm{d}} \times \frac{4}{\pi}$

in which $\bar{d}=$ average diameter of all visible nuclei in sections. Measurement of the mean nuclear diameter permitted us to compute nuclear volume $(v)$ and to estimate the total number of cells in the testis by the ratio $V / v$.

We measured the diameter of the following germ cells (see Table 1): 
Spermatogonia $A\left(\mathrm{G}_{\mathrm{A}}\right)$ : these cells were found isolated or in groups of 2 . There seemed to be several types, including primordial germ cells, but since we could not distinguish them, they were grouped together as $\mathrm{G}_{\mathrm{A}}$.

Spermatogonia $B\left(\mathrm{G}_{\mathrm{B}}\right)$ : these cells were grouped together in cysts. Several generations of unknown number were found. Their nuclear diameter was less when the cyst was larger, i.e. when more division occurred. Cyst samples of all sizes were measured so that the value of the mean size obtained included all the generations of $\mathrm{G}_{\mathrm{B}}$.

Spermatocytes I and II, spermatids at all stages, and spermatozoa

Table 1. Corrected nuclear diameter in $\mu \mathrm{m}$ of the germ cell and correction factor $K\left(V_{V}\right)$ for section thickness effect. The nuclear diameter $d$ was measured on around 30 cells taken from 5 males. Inter-male variation (analysis of variance) was not significant

\begin{tabular}{lll}
\hline & $\begin{array}{l}\text { Diameter } \\
(\mu \mathrm{m})\end{array}$ & $K V_{V}$ \\
\hline Type A spermatogonia & $9.07 \pm 0.33$ & 0.55 \\
Type B spermatogonia & $6.01 \pm 0.21$ & 0.44 \\
Priming spermatocytes & $5.77 \pm 0.19$ & 0.43 \\
Spermatids & $2.34 \pm 0.12$ & 0.24 \\
Spermatozoa & $2.18 \pm 0.18$ & 0.23 \\
\hline
\end{tabular}

We also analyzed such somatic structures as the lumen of the lobule, including the space occupied by spermatozoa, cyst cells (Sertoli cells) and pyknotic structures identified in the tubules and spermatophages. A study of the extra-lobular space included nuclear and cytoplasmic volumes.

The tables and figures give the mean results with SD; analysis of variance was used for comparison of the gonadosomatic index (GSI) after log transformation of the data.

\section{Results}

\section{Patterns of spermatogenesis during the annual reproductive cycle}

Gonadosomatic index (GSI) and sperm production. Body and testicular weight as well as the volume and concentration of the sperm collected during spermiation are shown on Table 2 . When the testis was resting, gonadal weight was extremely low. The greatest weights, recorded in April, were due to spermatozoa from the previous cycle that remained in the testis and were being resorbed. Testicular weight increased considerably in September but the high variation accompanying the mean GSI (Fig. 1) showed that the onset of spermatogenesis was not strictly synchronous. The GSI was maximal in October but decreased significantly $(P<0.05)$ in November before spermiation began. It reached a new lower level again in February. The process of spermiation only began in December with all males producing sperm between December and February. This production per month (between 4 and $6 \mathrm{ml}$ ) until killing, was constant during that period, although the males were not sampled on the concentration of spermatozoa in the sperm decreased markedly $(P<0.01)$ (Table 2$)$.

The changes in some somatic and structural components of the testis are shown in Fig. 1. The size of the lobular lumen changed with the GSI; during the testicular resting stage (June to August), this lumen was practically non-existent. It increased with testicular activity and was very distended 


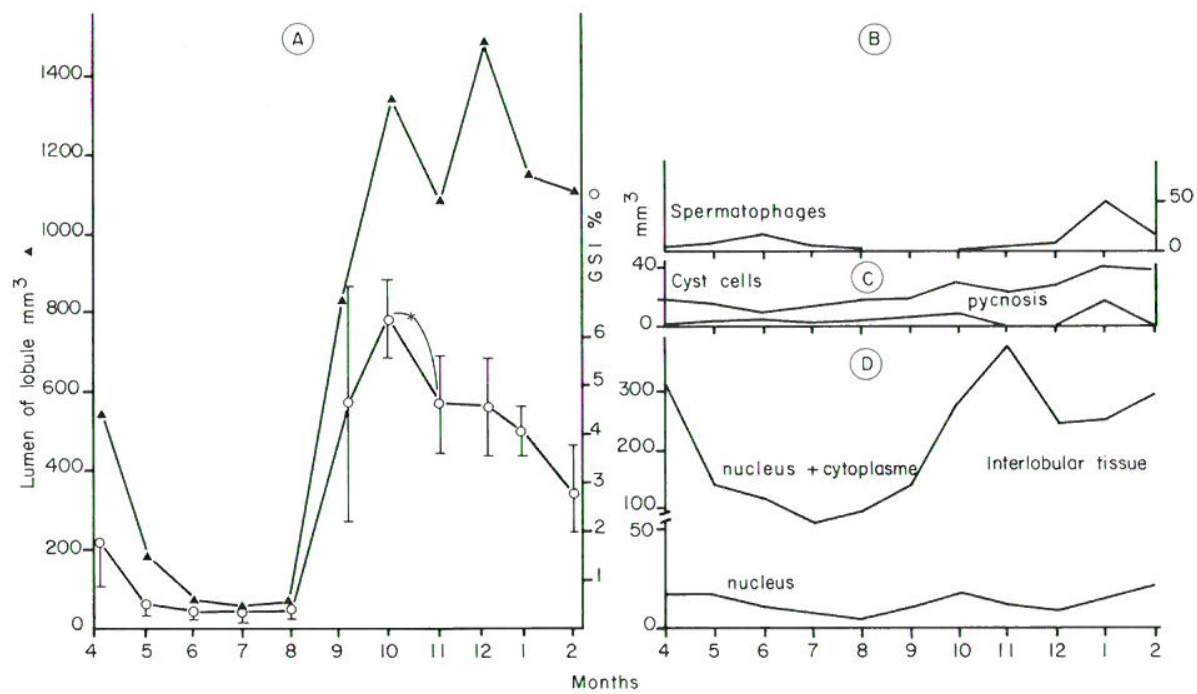

Fig. 1A-D. Development of structures and testicular somatic cells during spermatogenesis in the brown trout. Results are expressed in $\mathrm{mm}^{3}$ in 2 testes after correction $K\left(V_{V}\right)$. A gonadosomatic index (GSI-circles) and volume of lobular lumen (triangles); B spermatophages in the lobular lumen; $\mathbf{C}$ cyst cells and pyknosis; $\mathbf{D}$ extra-lobular connective tissue

when the spermatozoa appeared, then augmented considerably again at the onset of spermiation. In January-February, spermatophages (Fig. 1 B) appeared. The cyst cells (equivalent to the Sertoli cells) also showed considerable phagocytic activity, and pyknotic structures appeared in the cytoplasm (Fig. 1C). The nuclear diameter of the cyst cells also increased, augmenting the volume occupied by the nuclear structures (Fig. 1C) which then reached their highest levels. A study of the cytoplasmic and the nuclear structures of the interstitial tissue showed that the cytoplasmic varied more than the nuclear structures (Fig. 1D).

Analysis of numbers of germ cells (Table 2) indicated that the $G_{A}$ remained relatively constant throughout the cycle; $G_{B}$ were present in low numbers in April, May and June, multiplied actively in September-October and then disappeared in December. The temporal pattern of spermatocytes I was analogous. There were a few spermatids between June and August, an abundance in September-October, but none in December. Some spermatozoa from the previous cycle subsisted in the testes until May (see GSI) when they were gradually resorbed. Between September and December, the quantity of spermatozoa produced during the new cycle increased regularly. Spermiation began in December and the number of testicular spermatozoa remained stable during the next 2 months.

Sperm production, computed from the estimated number of germ cells per sample (Table 3), was in all about $3.3 \times 10^{11}$ spermatozoa/cycle or, if mean testicular weight between November and February was considered, about $2.5 \times 10^{10} / \mathrm{g}$ of testis. Da production was about $610^{9}$ spermato$\mathrm{zoa} / \mathrm{g}$ of body weight over the year or $\$ .6 \times 10^{5} / \mathrm{g}$ of body weight/day. 
Table 2. Body and testicular weight and sperm production in trout sampled periodically during a reproductive cycle (mean $\pm \mathrm{SD})$

\begin{tabular}{|c|c|c|c|c|c|c|}
\hline Month & $n$ & $\begin{array}{l}\text { Body } \\
\text { weigth } \\
\text { (g) }\end{array}$ & $\begin{array}{l}\text { Testicular } \\
\text { weight }^{\mathrm{a}} \\
(\mathrm{g})\end{array}$ & $\begin{array}{l}\text { No. of } \\
\text { males } \\
\text { producing } \\
\text { sperm }\end{array}$ & $\begin{array}{l}\text { Volume } \\
\text { of sperm } \\
\text { recovered } \\
(\mathrm{ml})^{\mathrm{b}}\end{array}$ & $\begin{array}{l}\text { Sperm } \\
\text { con- } \\
\text { centration } \\
10^{9} \mathrm{spz} / \mathrm{ml}\end{array}$ \\
\hline April & 10 & $216 \pm 29$ & $3.86 \pm 2.6$ & 0 & & \\
\hline May & 9 & $208 \pm 22$ & $1.04 \pm 0.46$ & 0 & & \\
\hline June & 9 & $241 \pm 35$ & $0.74 \pm 0.31$ & 0 & & \\
\hline July & 8 & $227 \pm 30$ & $0.71 \pm 0.27$ & 0 & & \\
\hline August & 10 & $274 \pm 60$ & $0.92 \pm 0.57$ & 0 & & \\
\hline September & 5 & $289 \pm 76$ & $16.95 \pm 1.5$ & 0 & & \\
\hline October & 5 & $279 \pm 64$ & $17.95 \pm 6.0$ & 0 & & \\
\hline November & 5 & $335 \pm 15$ & $16.15 \pm 6.0$ & 0 & & \\
\hline December & 5 & $303 \pm 6.9$ & $12.82 \pm 2.6$ & 5 & $4.40 \pm 1.22$ & $15,487 \pm 0.99$ \\
\hline January & 5 & $364 \pm 47$ & $12.81 \pm 2.8$ & 5 & $6.05 \pm 1.05$ & $10,240 \pm 1.02$ \\
\hline February & 6 & $374 \pm 50$ & $10.37 \pm 4.7$ & 6 & $4.33 \pm 2.35$ & $9.850 \pm 1.51$ \\
\hline
\end{tabular}

a Weight of both testes without sperm; sperm volume given in the last column

b Sperm density $=1.11$

Table 3. Estimate of the number of germ cells $\left(10^{6}\right)$ /pair of testes at different months of the annual cycle, calculated from the total volume of the nuclear structures of each stage/nuclear volume of the corresponding stage (Table 2)

\begin{tabular}{rrrrrrl}
\hline Months & $\mathrm{G}_{\mathrm{A}}$ & $\mathrm{G}_{\mathrm{B}}$ & $\begin{array}{l}\text { Spermato- } \\
\text { cytes } \mathrm{I}\end{array}$ & Spermatids & $\begin{array}{l}\text { Testicular } \\
\text { spermatozoa }\end{array}$ & $\begin{array}{l}\text { Total } \\
\text { spermatozoa }\end{array}$ \\
\hline 4 & 17.4 & 0 & 0 & 0 & 73,916 & \\
5 & 38.2 & 64.1 & 65.3 & 0 & 6,391 & \\
6 & 8.6 & 36.1 & 4.7 & 24 & 496 & \\
7 & 46.4 & 111.4 & 12.6 & 219 & 356 & \\
8 & 37.3 & 265.8 & 114.6 & 204 & 2,605 & \\
9 & 44.1 & $1,034.3$ & $6,827.7$ & 56,529 & 103,746 & \\
10 & 72.3 & $1,652.9$ & $10,764.7$ & 91,899 & 168,348 & \\
11 & 68.6 & 210.2 & $2,980.5$ & 28,428 & 216,394 & \\
12 & 82.7 & 0 & 0 & 5,668 & 279,353 & 347,496 \\
1 & 75.5 & 0 & 0 & 0 & 270,642 & 332,594 \\
2 & 48.7 & 0 & 0 & 0 & 275,870 & 318,520 \\
\hline
\end{tabular}

a Including the spermatozoa recovered from the sperm ducts before killing the males (see Table 2)

\section{Discussion}

A quantitative study of adult male spermatogenesis in the brown trout and its pattern during the reproductive cycle shows that the length of the entire process is relatively short. A large number of $G_{B}$ appear in August, and spermatozoa are present one month later. There are some abortive attempts to initiate spermatogenesis in May. Spermatogenetic activity is maximal in October; although the number of spermatozoa continues to increase in November, testicular weight and lobular lumen size decrease, 
probably due to elimination of the cytoplasm characteristic of spermiogenesis. In December, when the males are in spermiation, the volume of the lobular lumen increases, although testicular weight remains stable. This is probably due to the testicular hydration that usually accompanies the processes of sperm fluidification (Clemens et al. 1964).

During maximal testicular activity, the interstitial space expands, as previously reported in the stickleback (Ruby and McMillan 1975). It is difficult from a simple histological image to attribute this expansion to greater activity of the Leydig cells, but it could be possible because these cells have been reported in the interlobular space in rainbow trout (Billard et al. $1971 \mathrm{a}$; Hurk et al. 1978 a, b) and in other salmonids (Nagahama et al. 1978; Hoar and Nagahama 1978), and circulating androgen levels are maximal at the end of spermatogenesis and during spermiation (Sanchez-Rodriguez et al. 1978; Billard et al. 1978, 1982; Scott et al. 1980; Stuart-Kregor et al. 1981; Fostier et al. 1982; Hunt et al. 1982). However, it has been reported that spermatogenesis is not always correlated with signs of Leydig cell activity (see Swarup and Srivastava 1978 for discussion), indicating that there may be other sources of androgen (Dood 1972).

An estimate of the number of germ cells provides more information than the simple expression of their total volume in the testis, but the method is limited by chances for error owing to difficulty in determining the exact volume of each individual cell.

The mean sperm production computed here $\left(2-3 \times 10^{10}\right.$ spermatozoa/g of testis) is about the same as that measured directly on mature males of the same species (Billard, unpublished data). The rainbow trout has a slightly higher production $\left(5.8 \times 10^{10}\right.$; Billard et al. $\left.1971 \mathrm{~b}\right)$ and sperm measured in the Atlantic salmon reaches $5.5 \times 10^{10}$ spermatozoa/g (Kasakov 1978). It is difficult to compare and validate these data owing to species differences and to variations in testicular weight, independent of the number of spermatozoa (see Tables 2, 3 and following discussion). If we accept the numerical data with a reasonable margin of error, some facts are evident. The mean number of $\mathrm{G}_{\mathrm{A}}$ permanently present in the testis is about $5 \times 10^{7}$. This number is clearly higher than the number of primordial germ cells (about 3000) counted before or during sex differentiation in the rainbow trout (Lebrun 1977; Lebrun et al. 1982) and the Atlantic salmon (Persov 1966), indicating that intense multiplication occurs before puberty. Moreover, this number may change between puberty and the following reproductive cycles since sperm production is lower during the first cycle (Billard 1974). It is also likely that the $G_{A}$ divide several times during spermatogenesis because, if one $\mathrm{G}_{\mathrm{A}}$ produced only one generation, 13 divisions would be implicated (cell increase from $5 \times 10^{7}$ to $3.3 \times 10^{11}$ ) or 12 spermatogonial divisions, which would be impossible considering the small size of the cysts. Therefore, all or part of the $\mathrm{G}_{\mathrm{A}}$ must produce several waves in one season. However, for reasons that are still unclear, $\mathrm{G}_{\mathrm{A}}$ sometimes stop dividing. This arrest may be due to distension of the lobules by spermatozoa since after exogenous gonadotropic hormone supply at the end of spermatogenesis, new waves of spermatogenesis are initiated only after most of the spermatozoa of the lobules have been eliminated (Billard et al. 1982). Towards 
the end of spermatogenesis, the last waves seem to again end in the formation of spermatozoa because the number of spermatozoa continues to increase while $G_{B}$, spermatocytes and spermatids are present. However, the number of spermatozoa does not increase in December while the testis still contains spermatids. In another study in the same species, Billard and Hill (unpublished data) clearly noted that the presence of spermatocytes and spermatids at the end of spermatogenesis was not related to the increase in the number of spermatozoa. We could not compute the yield of different stages because we lack information on the length of these stages.

While sperm production by the testis is high, the amount of sperm recovered was low (about 15 p. 100 of the total spermatozoal content of the testis) which is similar to the values reported with infrequent sampling in the rainbow trout (Billard et al. 1971). The volume of sperm recovered does not increase between December and February, as if spermiation had stopped in December. On the other hand, the number of testicular spermatozoa remains stable during the same period although some spermatozoa are resorbed by and increased number of spermatophages in January and the cyst cells began phagocytosis at the same time. The process of resorption, already described in the rainbow trout (Billard et al. 1972; Billard et Takashima 1983), also occurs in other species such as the stickleback, Eucalia inconstans (Ruby and Mc Millan 1970). The decrease in gonadal weight observed between December and February may be due also to water loss supressing spermatozoal migration outside the testis, i.e. spermiation in December, which would explain the low spermatozoal release.

Acknowledgements. We wish to thank Anne-Marie Escaffre for her assistance, Aline Solari for helpful comments on the paper and Alice Daifuku for the English translation.

\section{References}

Bhatti N, Al-Daham NK (1978) Annual cyclical changes in the testicular activity of a freshwater teleost, Barbus luteus (Heckel) from Shatt-Al-Arab, Iraq. J Fish Biol 13:321-326

Billard R (1969) La spermatogénèse de Poecilia reticulata I - Estimation du nombre de générations goniales et rendement de la spermatogénèse. Ann Biol Anim Biochim Biophys 9:251-271

Billard R (1974) La production spermatogénétique de la truite arc-en-ciel au cours du premier cycle reproducteur. Bull Fr Pisc 253:140-149

Billard R, Takashima R (1983) Resorption of spermatozoa in the spermduct of rainbow trout (Salmo gairdneri) during the post-spawning period. Jpn Bull Soc Sci Fish, in press

Billard R, Meusy-Dessoles N, Flechon JE (1971 a) Les cellules interstitielles de quelques poissons téléostéens. J Microscopie 11:30

Billard R, Breton B, Jalabert B (1971 b) La production spermatogénétique chez la truite. Ann Biol Anim Biochim Biophys 11:190-212

Billard R, Jalabert B, Breton B (1972) Les cellules de Sertoli des poissons téléostéens. Ann Biol Anim Biochim Biophys 12:19-32

Billard R, Solari A, Escaffre AM (1974) Méthode d'analyse quantitative de la spermatogénèse des poissons téléostéens. Ann Biol Anim Biochim Biophys 14:87-104

Billard R, Breton B, Fostier A, Jalabert B, Weil C (1978) Endocrine control of the teleost reproductive cycle and its relation to external factors: salmonid and cyrpinid models. In: Gaillard PJ, Boer JJ (eds) Comparative endocrinology. Elsevier/North-Holland Biomedical Press, Amsterdam, pp 37-48

Billard R, Fostier A, Weil C, Breton B (1982) Endocrine control of spermatogenesis in teleost fish. Can J Fish Aquat Sci 39:65-79 
Clemens HP, Ciereszko LS, Shoemaker JD, Grant FB (1964) Partial characterization of the gonadal hydration principle in the pituitaries of carp (Cyprinus carpio). Gen Comp Endocrinol 4:503-507

Dodd JM (1972) The endocrine regulation of gametogenesis and gonad maturation in fishes. Gen Comp Endocrinol Suppl 3:675-687

Fostier A, Billard R, Breton B, Legendre M, Marlot S (1982) Plasma 11-oxotestosterone and gonadotropin during the beginning of spermiation in rainbow trout (Salmo gairdneri R.). Gen Comp Endocrinol 46:428-434

Henning A, Meyer-Arendt JR (1963) Microscopic volume determination and probability. Lab Invest 12:460-464

Hoar WS, Nagahama Y (1978) The cellular sources of sex steroids in teleost gonads. Ann Biol Anim Biochim Biophys 18:893-898

Hunt SMV, Simpson TH, Wright RS (1982) Seasonal changes in the levels of 11-oxotestosterone and testosterone in the serum of male salmon, Salmo salar L., and their relationship to growth and maturation cycle. J Fish Biol 20:105-119

Hurk Van den R, Vermeij JAJ, Stegenga J, Peute J, Van Oordt PGWJ (1978a) Cyclic changes in the testis and vas deferens of the rainbow trout (Salmo gairdneri) with special reference to sites of steroidogenesis. Ann Biol Anim Biochim Biophys 18:899-904

Hurk Van den R, Peute J, Vermeij JAJ (1978b) Morphological and enzyme cytochemical aspects of the testis and vas deferens of the rainbow trout Salmo gairdneri. Cell Tissue Res 186:309-325

Kasakov RV (1978) Some peculiarities in producing of sperm and dependence of its quality on age, weight and frequency of participating in spawning of atlantic salmon males. ISV.GOSUDARSTVENNOGO 129:94-102

Lebrun C (1977) Differenciation sexuelle des gonades chez la truite arc-en-ciel. Thèse 3ème cycle, Univ Paris VI $41 \mathrm{pp}$

Lebrun C, Billard R, Jalabert B (1982) Changes in the number of germ cells in the gonads of the rainbow trout (Salmo gairdneri) during the first 10 post-hatching weeks. Reprod Nutr Dev 22:405-412

Nagahama Y, Clarke WC, Hoar WS (1978) Ultrastructure of putative steroid-producing cells in the gonads of coho (Oncorhynchus kisutch) and pink salmon (Oncorhynchus gorbuscha). Can J Zool 56:2508-2519

Persov GM (1966) Early stages of gametogenesis in deadromous salmon. Fish Res Board Canada, Transl series n ${ }^{\circ} 2849$

Ruby SM, Mc Millan DB (1970) Cyclical changes in the testis of the brook stickleback Eucalia inconstans (Kirtland). J Morphol 131:447-466

Ruby SM, Mc Millan DB (1975) The interstitial origin of germinal germ cells in the testis of the stickleback. J Morphol 1453:295-318

Sanchez-Rodriguez M, Escaffre AM, Marlot S, Reinaud P (1978) The spermiation period in the rainbow trout (Salmo gairdneri). Plasma gonadotropin and androgen levels, sperm production and biochemical changes in the seminal fluid. Ann Biol Anim Biochim Biophys 18:943-948

Scott AP, Bye VJ, Baynes SM, Springate JRC (1980) Seasonal variations in plasma concentrations of 11-ketotestosterone and testosterone in male rainbow trout, Salmo gairdnerii Richardson. J Fish Biol 17:495-505

Solari A (1973) Etude quantitative d'organes ou de tissus. I. Méthodes d'estimation des volumes. Ann Biol Anim Biochim Biophys 13:247-265

Stuart-Kregor PAC, Sumpter JP, Dodd JM (1981) The involvement of gonadotropin and sex steroids in the control of reproduction in the parr and adults of Atlantic salmon, Salmo salar L. J Fish Biol 18:59-72

Swarup K, Srivastava S (1978) Cyclic changes in the testicular activity of the freshwater large murrel Channa striatus (Bloch). Arch Biol 89:329-342

Underwood EE (1970) Quantitative stereology. Addison-Wesley Publish Comp Reading Massachusetts, p 274

Weibel ER (1979) Stereological methods. Practical methods for biological morphometry, Vol. I, Academic Press, London, New York, Toronto, Sydney, San Francisco 